\title{
PENGARUH PERPUTARAN MODAL KERJA TERHADAP PROFITABILITAS PADA PERUSAHAAN MANUFAKTUR YANG TERDAFTAR DI BURSA EFEK INDONESIA
}

\author{
Rian Maming \\ Email : rian_maming@stiem.ac.id \begin{abstract}
Muhammadiyah Palopo
\end{abstract} \\ Program studi Ilmu Ekonomi dan Studi Pembangunan, Sekolah Tinggi Ilmu Ekonomi
}

\begin{abstract}
Abstrak
Penelitian ini bertujuan untuk mengetahui pengaruh perputaran modal kerja terhadap profitabilitas pada perusahaan manufaktur yang terdaftar di bursa efek indonesia. Metode yang digunakan dalam penelitian ini adalah analisis regresi linier sederhana dengan menggunakan program aplikasi SPSS versi 23. Hasil penelitian menunjukkan bahwa variabel perputaran modal kerja memiliki hasil positif dan berpengaruh tidak signifikan terhadap profitabilitas
\end{abstract}

\section{Kata Kunci : Perputaran Modal Kerja, Profitabilitas, Perusahaan Manufaktur}

\section{PENDAHULUAN}

\section{Latar Belakang}

Bursa efek atau bursa saham adalah sebuah pasar yang berhubungan dengan pembelian dan penjualan efek perusahaan yang sudah terdaftar di bursa itu. Bursa efek tersebut bersama-sama dengan pasar uang merupakan sumber utama permodalan eksternal bagi perusahaan dan pemerintah. Di dalam bursa efek terdapat beberapa perusahaan, yang dimana salah satunya adalah perusahaan manufaktur. Perusahaan manufaktur adalah perusahaan industri pengolahan yang mengolah bahan baku menjadi barang setengah jadi atau barang jadi. Perusahaan manufaktur identik dengan pablik yang mengaplikasikan mesin-mesin peralatan Teknik rekayasa dan tenaga kerja.

Kebutuhan masyarakat yang semakin banyak merupakan akibat dari kebutuhan manusia yang tidak terbatas yang diikuti dengan perkembangan pola berpikir manusia yang semakin maju dan kecanggihan teknologi. Hal ini menyebabkan perkembangan dunia usaha yang semakin meningkat dan timbul persaingan yang kompetitif di antara perusahaan yang beragam bentuk usahanya. Perusahaan yang kuat akan bertahan hidup.sebaliknya perusahaan yang tidak mampu bersaing kemungkinan akan dilikuidasi atau mengalami kebangkrutan. Tujuan utama perusahaan pada umumnya ialah memperoleh laba atau keuntungan yangsemaksimal mungkin.

Perputaran modal kerja merupakan perbandingan antara penjualan dengan jumlah keseluruhan aktiva lancar yang dimiliki suatu perusahaan pada suatu periode akuntansi tertentu. Semakin besar rasio ini menunjukan efektifnya pemanfaatan modal kerja yang tersedia dalam meningkatkan profitablilitas perusahaan.Ini berarti bahwa semakin besar rasio perputaran modal kerja maka semakin baik suatu perusahaan dimana persentase modal kerja yang ada mampu menghasilkan jumlah penjualan tertentu.

Tingkat perputaran modal kerja mengukur berapa kali aktiva lancar mampu berputar untuk menghasilkan penjualan.Semakin cepat modal kerja berputar semakin banyak penjualan yang berhasil tercipta. Dengan peningkatan penjualan diharapkan terjadi peningkatan profitabilitas.

Bagi suatu perusahaan untuk memperoleh laba yang maksimal, dapat dilakukan dengan memperbesar jumlah produksi yang dapat dijual. Salah satu faktor produksi terpenting ialah modal kerja yang digunakan perusahaan untuk membiayai operasi perusahaan demi menjamin kelangsungan hidup perusahaan. Modal kerja adalah dana yang ditanamkan ke dalam aktiva lancar untuk membiayai operasi perusahaan seharihari. Modal kerja dalam suatu perusahaan selalu dalam keadaan operasi atau berputar. oleh sebab itu perlu dilakukan pengelolaan yang baik terhadap modal kerja. Pada hakekatnya perputaran modal kerja mempunyai hubungan yang sangat erat dengan keuntungan atau tingkat profitabilitas perusahaan. Profitabilitas suatu perusahaan menunjukkan kemampuan perusahaan memperoleh laba dalam hubungannya dengan penjualan.total aktiva.maupun modal sendiri. Tingkat profitibalitas yang ada dalam sebuah perusahaan akan diukur menggunakan rasio profitabilitas. Rasio profitabilitas akan memberikan gambaran tentang tingkat efektifitas pengelolaan perusahaan. Semakin besar profitabilitas berarti semakin baik.karena kemakmuran pemilik perusahaan meningkat dengan semakin besarnya profitabilitas. Rasio profitabilitas yang digunakan dalam penelitian ini adalah marjin laba bersih (net profit margin). Disebut juga dengan rasio pendapatan terhadap penjualan. Margin laba bersih sama dengan laba bersih dibagi dengan penjualan bersih. Ini menunjukan kestabilan kesatuan yang menghasilkan perolehaan pada tingkat penjualan khusus. 
Dalam hubungannya dengan uraian tersebut diatas. Maka fenomena yang terjadi dalam perushaan manufaktur pada profitabilitas perusahaan mengalami fluktuasi.Dimana faktor yang menyebabkan adanya

Tabel 1.1

perusahaan yang mengalami fluktuasi selama ini.karena adanya kenaikan penjualan yang dilakukan oleh perusahaan selama 3 tahun terakhir. Hal ini dapat di jelaskan melalui tabel 1.1 yaitu sebagai berikut

\section{Perputaran Modal Kerjadan Net Profit Margin yangTerdaftar di Bursa Efek Indonesia (BEI) \\ Tahun 2013-2015}

\begin{tabular}{|c|l|r|r|r|r|r|r|}
\hline \multirow{2}{*}{ No } & \multirow{2}{*}{ Nama Perusahaan } & \multicolumn{3}{|c|}{ PerputaranModal } & \multicolumn{3}{c|}{ LabaBersih } \\
\cline { 3 - 9 } & & $\mathbf{2 0 1 3}$ & $\mathbf{2 0 1 4}$ & $\mathbf{2 0 1 5}$ & $\mathbf{2 0 1 3}$ & $\mathbf{2 0 1 4}$ & $\mathbf{2 0 1 5}$ \\
\hline 1 & PT. Nippon indosaricorpindoTbk & 3.45 & 1.66 & 5.21 & 0.10 & 0.10 & 0.12 \\
\hline 2 & PT. TriasSentosaTbk & 1.36 & 1.10 & 9.17 & 0.18 & 0.02 & 8.73 \\
\hline 3 & PT. fajarSuryawisesaTbk & 9.02 & -1.27 & -2.95 & -0.05 & 0.02 & 0.17 \\
\hline 4 & PT. IndospringTbk & 2.22 & 5.02 & -1.97 & 0.24 & 0.67 & 0.08 \\
\hline 5 & PT. MayoraIndahTbk & 3.20 & -5.76 & 3.30 & 0.09 & 2.03 & 0.08 \\
\hline \multirow{2}{*}{6} & PT. Ultra Jaya Milk Industry And & & & & & & \\
\hline 7 & Trading Tbk & 3.72 & 3.70 & 3.70 & 0.09 & 0.07 & 0.12 \\
\hline 8 & PT. KimiaFarmaTbk & 4.10 & 3.80 & 4.81 & 4.95 & 0.06 & 0.04 \\
\hline 9 & PT. TalbeFarmaTbk & 8.95 & 3.03 & -1.61 & 0.05 & 0.12 & 0.12 \\
\hline 10 & PT.IndoMomo Scan Pacific Tbk & 2.60 & 3.03 & 3.15 & 0.98 & 0.07 & 0.07 \\
\hline
\end{tabular}

Sumber :Hasil olah data

Berdasarkan tabel 1.1 yakni data perputaran modal kerja terhadap profitabilitas (NPM) dapat di simpulkan bahwa perusahaan manufaktur selama 3 tahun terakhir yakni:

1. Perusahaaan yang mengalami peningkatan modal kerja ada dua yaitu. PT. Trias Sentosa Tbk dan PT. Tempo Scan Pacific Tbk.

2. Perusahaan yangmengalami fluktuasi modal kerjaada lima yaitu.

PT. Nippon indosari corpindo Tbk. PT. Mayora Indah Tbk. PT. Ultra Jaya Milk Industry And Trading Tbk. PT. Kimia Farma Tbk.PT. Indo Mobil Sukses Internasional Tbk.

3. Perusahaan yang mengalami penurunan modal kerja ada dua yaitu. PT. Indospring Tbk. PT. fajar Surya wisesa Tbk.

4. Laba bersih pada perushaan yang mengalami kenaikan ada tiga yaitu. PT. Nippon indosari corpindo Tbk.PT. Indo Mobil Sukses Internasional Tbk.

Laba bersih yang mengalamami fluktuasi ada tujuh yaitu. PT. Trias Sentosa Tbk. PT. Indospring Tbk. PT. Mayora Indah Tbk. PT. Ultra Jaya Milk Industry And Trading Tbk. PT. Kimia Farma Tbk. PT. Kalbe Farma Tbk. PT. Tempo Scan Pacific Tbk.

\section{KAJIAN TEORI}

\section{Laporan Keuangan}

Laporan keuangan merupakan ringkasan dari transaksi-transaksi keuangan yang terjadi selama tahun buku yang bersangkutan.Laporan keuangan ini bertujuan untuk mengetahui kondisi dan posisi perusahaan pada saat ini atau dalam suatu periode tertentu.Biasanya laporan keuangan dibuat per periodemisalnya tiga bulan.atau enam bulan untuk kepentingan intern perusahaan dan adapun untuk laporan lebih luas dilakukan 1 tahun sekali. Laporan keuangan juga akan menentukan langkah apa yang yang dilakukan perusahaan sekarang dan ke depan. Dengan melihat berbagai persoalan yang ada. Baik kelemahan maupun kekuatan yang dimiliki perusahaan dalam memanfaatkan peluang yang ada dan menghadapi atau menghindari ancaman yang mungkin timbul sekarang dan dimasa yang akan datang.

\section{Teori Modal Kerja}

Perusahaan yang bergerak dibidang apapun baik itu perusahan jasa maupun perusahaan produksi barang selalu membutuhkan modal kerja untuk membiayai kegiatan usahanya.dengan harapan dana yang telah dikeluarkan dapat kembali masuk ke dalam perusahaan dalam jangka yang relatif pendek. Modal kerja merupakan modal yang digunakan untuk membiayai operasional perusahaan sehari-hari.terutama yang memiliki jangka waktu pendek. Modal kerja juga diartikan seluruh aktiva lancar yang dimiliki suatu perusahaan atau setelah aktiva lancar dikurangi dengan utang lancar atau dengan kata lain modal kerja merupakan investasi yang ditanamkan dalam aktiva lancar atau aktiva jangka pendek. seperti kas bank surat berharga piutang sediaan dan aktiva lancar lainnya. Biasanya modal kerja digunakan untuk beberapa kali kegiatan dalam satu periode. 
Adapun faktor-faktor yang dapat mempengaruhi modal kerja antara lain tergantung dari:
1. Jenis Perusahaan
2. Syarat Kredit
3. Waktu Produksi
4. Tingkat Perputaran Sediaan

\section{Perputaran Modal Kerja}

Antara penjualan dengan modal kerja terdapat hubungan yang erat. Bila volume penjualan naik investasi persediaan dan piutang juga meningkat. ini berarti juga meningkatkan modal kerja. Untuk menguji efisiensi penggunaan modal kerja. peneliti dapat menggunakan perputaran modal kerja (working capital turnover). Working Capital Turnover (WCT) yaitu rasio yang memperlihatkan adanya keefektifan modal kerja dalam pencapaian penjualan. Menurut Riyanto (2013:62). yang menyatakan bahwa perputaran modal kerja atau working capital turn over merupakan salah satu rasio untuk mengukur atau menilai keefektifan modal kerja perusahaan selama periode tertentu. Artinya seberapa banyak modal kerja berputar selama satu periode atau dalam satu periode.

\section{Profitabilitas}

Profitabilitas adalah kemampuan perusahaan memperoleh laba dalam hubungannya dengan penjualan.total aktiva.maupun modal sendiri. Sartono (2010:130).Jumlah laba bersih kerap dibandingkan dengan ukuran kegiatan atau kondisi keuangan lainnya seperti penjualan.aktiva.ekuitas pemegang saham untuk menilai kinerja sebagai suatu persentase dari beberapa tingkat aktivitas atau investasi.Perbandingan ini disebut rasio profitabilitas (profitability ratio). Faktor-faktor Lain yang Dapat Mempengaruhi Profitabilitas yaitu :
1. Profit margin.yaitu perbandingan antara "net operating income' dengan "Net Sales".

2. Turnover of operating assets (tingkat perputaran aktiva usaha).yaitu kecepatan berputarnya operating assets dalam suatu periode tertentu.

\section{METODE PENELITIAN}

\section{Tempat Dan Waktu Penelitian}

Penelitian ini akan dilakukan pada Bursa Efek Indonesia Kantor Perwakilan Makassar yang berlokasi di JL. DR. Sam Ratulangi No 124 Makassar selama penelitian \pm 1 bulan.

\section{Populasi dan Sampel}

\section{Populasi}

Populasi dalam penelitian ini adalah perusahaan manufaktur yang terdaftar di BEI (Bursa Efek Indonesia) untuk tahun 2013 - 2015.

\section{Sampel}

Sampel yang digunakan dalam penelitian ini mengunkan metode purposive sampling yaitu metode mengambil sampel data dengan pertimbangan dan kriteria tertentu. Adapun kriteria yang menjadi pertimbangan dalam menentukan sampel adalah:

1. Perusahaan manufaktur yang terdaftar di BEI pada tahun2013-2015.

2. Menerbitkan laporan tahunan lengkap selama tahun2013-2015.

3. 10 perusahaan berdasarkan asset yang tertinggi 2013-2015.

Tabel 3.1 Sampel Perusahaan

\begin{tabular}{|l|l|c|}
\hline No & \multicolumn{1}{|c|}{ Nama Perusahaan } & Kode \\
\hline 1 & PT. Nippon Indosari Corpindo Tbk. & ROTI \\
\hline 2 & PT. Trias Sentosa Tbk. & TRST \\
\hline 3 & PT. Fajar Surya Wisesa Tbk. & FASW \\
\hline 4 & PT. Indospring Tbk. & INDS \\
\hline 5 & PT. Mayora Indah Tbk. & MYOR \\
\hline 6 & PT. Ultra Jaya Milk Industry And Trading Tbk. & ULTJ \\
\hline 7 & PT. Kimia Farma Tbk. & KAEF \\
\hline 8 & PT. Kalbe Farma Tbk. & KLBF \\
\hline 9 & PT. Tempo Scan Pasific Tbk. & TSPC \\
\hline 10 & PT. Indomobil Sukses Internasional Tbk. & IMAS \\
\hline
\end{tabular}

Sumber:www.idx.com 


\section{Definisi Operasional}

\section{Variabel Terikat (Dependent Variable)}

Variabel terikat dalam penelitian ini adalah profitabiloitas. profitabilitas dapat dilihat dari segi analisis laporan keuangan berupa rasio keuangan dan dari segi perubahan harga saham. Pada penelitian ini.profitabilitas diukur menggunakan Rasio keuangan yaitu net profit margin ( NPM ).

Net profit margin (NPM) dihitung dengan formula sebagai berikut:

$$
\mathrm{NPM}=\frac{\text { laba setelah pajak }}{\text { penjualan }} \times 100 \%
$$

\section{Variabel bebas (Independent Variable)}

Perputaran modal kerja adalah salah satu rasio untuk mengukur atau menilai keefektifan modal kerja perusahaan selama priode tertentu. Artinya seberapa banyak modal kerja berputar selama satu periode atau dalam satu periode.

Rumus perputaran modal kerja adalah sebagai berikut:

$$
\begin{aligned}
& \text { Perputaran modal kerja }= \\
& \frac{\text { hasil penjualan netto }}{\text { aktiva lancar-utang lancar }} \times 100 \%
\end{aligned}
$$

\section{Hasil Penelitian dan Pembahasan}

Tabel 4.1

Hasil Persamaan Regresi Mengenai Pengaruh Perputaran Modal Kerja Terhadap Profitabilitas Pada Perusahaan Sektor Manufaktur Yang Terdaftar Di Bursa Efek Indonesia

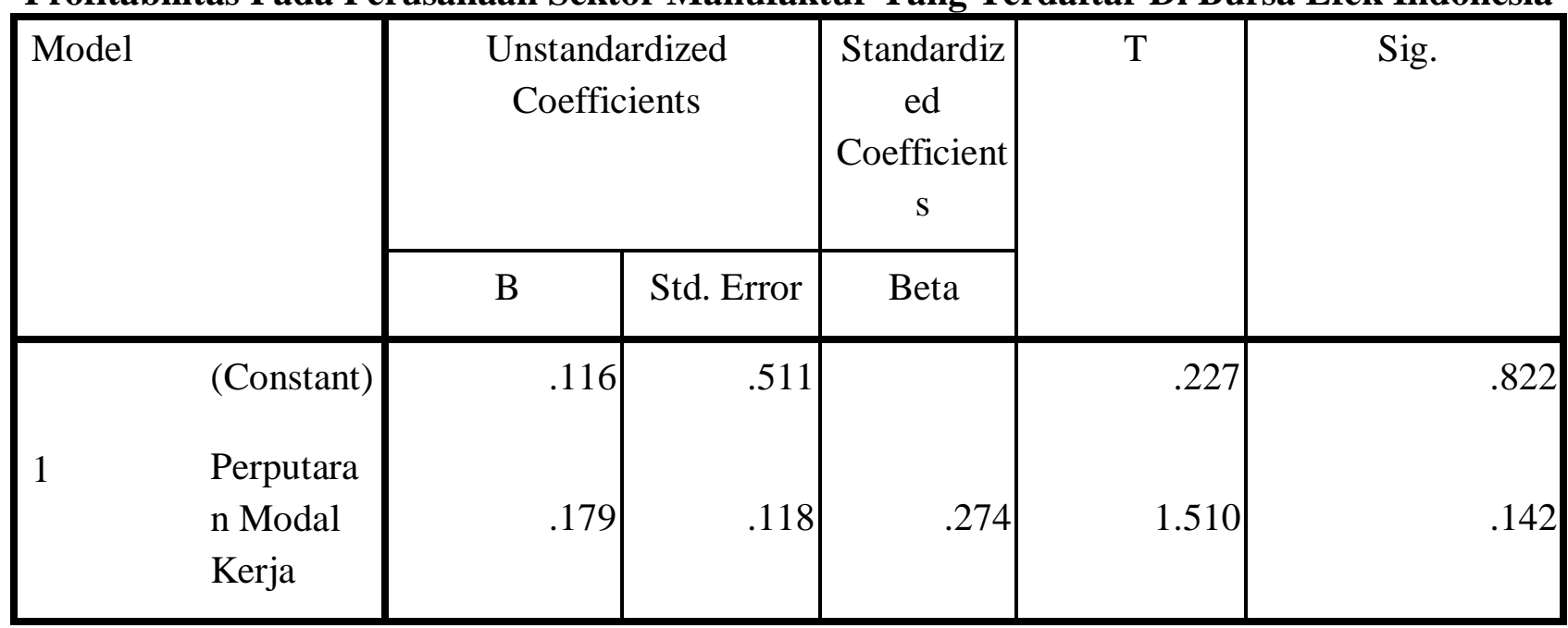

Sumber: Data diolah 2018

Dari hasil olahan data regresi melalui program komputerisasi (SPSS versi 20) nampak bahwa antara penilaian perputaran modal kerja dengan profitabilitas, maka diperoleh persamaan regresi adalah sebagai berikut:

$$
\mathbf{Y}=\mathbf{0 , 1 1 6}+\mathbf{0 , 1 7 9 X}+\mathbf{e}
$$
bahwa:

Dari persamaan diatas dapat diambil kesimpulan

1. Konstanta sebesar 0,116 atau konstanta bernilai positif,menyatakan bahwa jika ada perputaran modal kerja (X) konstan, maka profitabilitas pada perusahaan sektor manufaktur yang terdaftar di bursa efek Indonesia akan naik sebesar 0,116 denganasumsi $(\mathrm{X})$ tetap.

2. Koefisien regresi perputaran modal (X) sebesar 0,179 menyatakan bahwa setiap penambahan (karena tanda positif) perputaran modal baik yang dimiliki perusahaan, maka akan memungkinkan perusahaan tersebut memilliki profitabilitas yang lebih baik pada perusahaan sektor manufaktur yang terdaftar di bursa efek indonesia sebesar 0,179 dengan asumsi faktor lain tetap.

\section{Pengujian Hipotesis}

\section{Uji $\mathbf{t}-$ Test}

Untuk dapat menguji apakah ada pengaruh variable perputaran modal kerja terhadap profitabilitas pada perusahaan sektor manufaktur yang terdaftar di bursa efek indonesia, maka dapat dilakukan uji thitung dengan tingkat kepercayaan 95\%, dengan formulasi sebagai berikut: 
Uji t Untuk Variabel Perputaran Modal Kerja (X) Uji t untuk variable perputaran modal kerja (X) terhadap profitabilitas pada perusahaan sektor manufaktur yang terdaftar di bursa efek indonesia, dapat dilakukan dengan langkah-langkah sebagai berikut:

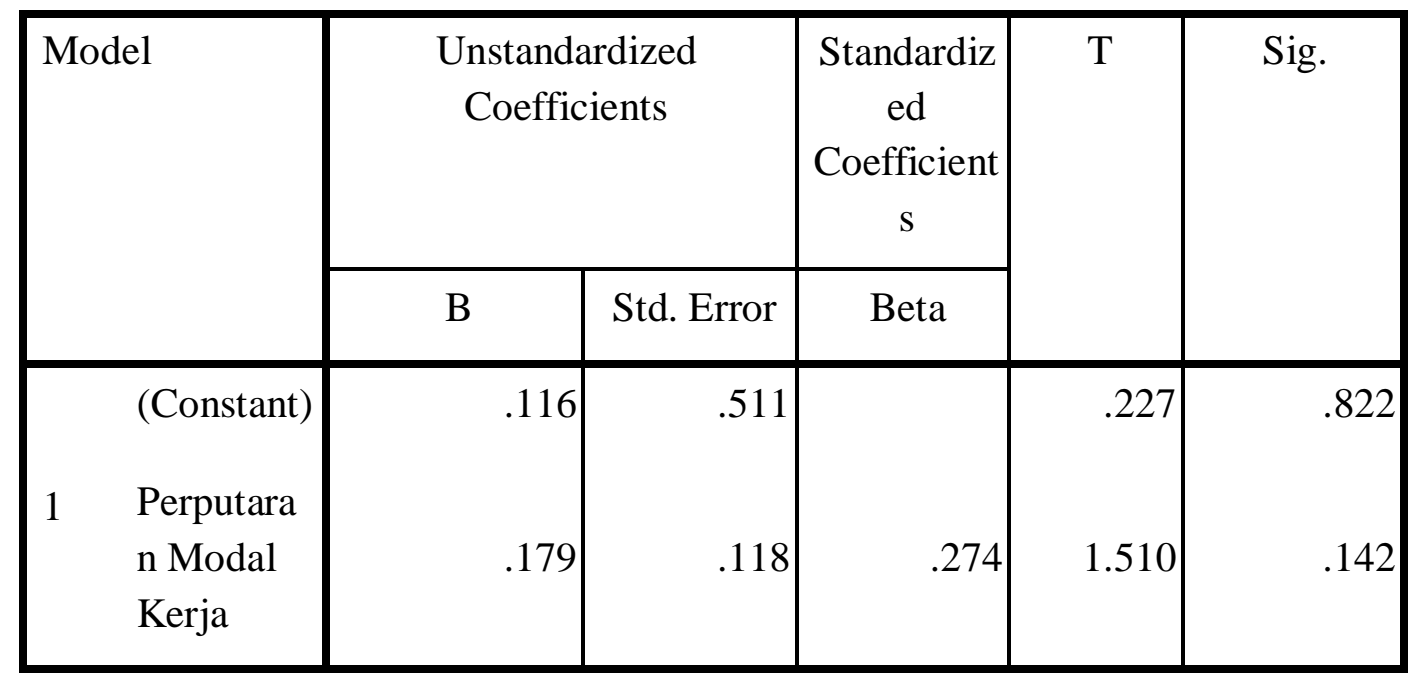

\section{Hipotesis}

Ho: $\beta 1 \leq 0 \quad$ Tidak ada pengaruh positif dari variabel perputaran modal kerja terhadap profitabilitas Ha: $\beta 1>0 \quad$ Semakin baik perputaran modal kerja yang terpenuhi maka semakin tinggi profitabilitas.

Hasil pengujian regresi untuk variabel perputaran modal kerja terhadap rofitabilitas menunjukkan nilai $\mathrm{t}$ hitung $=1.510$ dengan nilai signifikasi 0.142. Dengan menggunakan batas signifikasi 0.05 maka nilai signifikasi tersebut lebih besar dari 0.05 maka hipotesis dapat ditolak. Dengan demikian perputaran modal kerja yang kurang baik pada akhirnya menghasilkan profitabilitas yang kurang pula.

\section{Pembahasan}

Pembahasan terhadap analisis ini dilakukan berdasarkan tujuan penelitian untuk mengetahui dan menganalisis pengaruh perputaran modal kerja terhadap profitabilitas pada perusahaan manufaktur yang terdaftar di Bursa efek Indonesia.

Hasil perhitungan statistik menunjukkan bahwa variable perputaran modal kerjaterhadap Profitabilitas berpengaruh positif dan tidak signifikan secara parsial. Artinya apabila perputaran modal kerja perusahaan kurangbaik, maka akan memungkinkan profitabilitas akan kecil pula. Dari hasil perhitungan spss menunjukkan bahwa perputaran modal kerja memiliki pengaruh tidak signifikan terhadap profitabilitas, dimana perputaran modal kerja merupakan salah satu faktor yang sangat menunjang dalam perusahaan untuk mendapatkan profitabilitas

\section{Kesimpulan}

Berdasarkan uraian-uraian yang telah penulis paparkan terhadap data penelitian yang telah terkumpul kemudian diolah mengenai pengaruh perputaran modal kerja terhadap profitabilitaspada perusahaanmanufaktur yang terdaftar di Bursa Efek Indonesia, maka penulis dapat menarik beberapa kesimpulan yaitu Hasil analisis regresi sederhana menunjukkan bahwa perputaran modal kerja berpengaruh positif dan tidak signifikan terhadap profitabiltas karena bernilai positif 0.179 dan signifikasinya pada .142. nilai ini lebih besar dari 0,05 menunjukkan bahwa posiif tidak signifikan.

Berdasarkan hasil pengujian yang telah dilakukan dapat dilihat bahwa perputaran modal kerja secara parsial tidak signifikan terhadap profitabilitas pada perusahaan manufaktur yang terdaftar di Bursa Efek Indonesia.

\section{DAFTAR PUSTAKA}

Fahmi Irham. 2012. Pengantar Manajemen Keuangan.cetakan pertama.Penerbit : Alfabeta. Bandung

Hery. 2012.Mengenal dan Memahami Laporan Keuangan. cetakan pertama. Penerbit : CAPS. Jakarta

Husnan Suad dan Enny Pudjiastuti. 2012.Dasar-Dasar Manajemen Keuangan. edisi keenam cetakan pertama. Penerbit : UPP STIM YKPN. Yogyakarta

I Gusti Ayu Putu Istri Widya Santhi dan Sayu Ketut Sutrisna Dewi. 2014. Pengaruh Manajemen Modal Kerja Terhadap Tingkat Profitabilitas pada Perusahaan Makanan dan Minuman yang Terdaftar di Bursa Efek Indonesia Periode 2010-2013. 
I Made Dian Satriya dan Putu Vivi Lestari. 2014.Pengaruh Perputaran Modal Kerja Terhadap Profitabilitas Perusahaan. Jurnal Universitas Udayana (Unud) Bali

Kamaluddin dan Rini Indriyani. 2012.Manajemen Keuangan "Konsep dasar dan Penerapannya". edisi revisi. cetakan kedua. Penerbit : Mandar Maju. Bandung

Kasmir. 2010.Bank dan Lembaga Keuangan Lainnya. Penerbit : Raja Graffindo Pers. Jakarta

2013.Analisa Laporan Keuangan. edisi pertama. cetakan pertama. Penerbit Raja Grafindo Persada. Jakarta

Margaretha Farah. 2014. Dasar-Dasar Manajemen Keuangan.cetakan pertama. Penerbit : Dian Rakyat. Jakarta

Martono dan Agus Harjito. 2010.Manajemen Keuangan.edisi pertama.cetakan kedelapan Penerbit : Ekonisia Kampus FE UII : Yogyakarta

Riyanto Bambang. 2011. Dasar-dasar Pembelanjaan.edisi keempat. Penerbit BPFE. Yogyakarta.

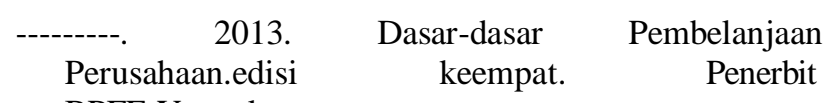
BPFE.Yogyakarta.

Rodoni Ahmad. dan Herni Ali. 2014.Manajemen Keuangan Modern. edisi pertama. cetakan pertama. Penerbit : Mitra Wacana Media. Jakarta

S. Munawir. 2010.Analisa Laporan Keuangan. Edisi keempat.cetakan keempat belas. Penerbit : Liberty. Yogyakarta.

Sawir. Agnes. 2010. Analisis Kinerja Keuangan dan Perencanaan Keuangan Perusahaan Penerbit :Gramedia pustaka umum. Jakarta

Sugiyono. 2011.Metode Penelitian Kombinasi (Mixed Methods).cetakan pertama.Penerbit : Alfabeta. Bandung

Sundjaja Ridwan S. dan Inge Barlian. 2003. Manajemen Keuangan.edisi kelima. Penerbit : Literata Lintas Media. Jakarta

Sunyoto Danang. 2013.Dasar-Dasar Manajemen Keuangan Perusahaan. edisi pertama.cetakan pertama.Penerbit : CAPS. Jakarta

Sutrisno. 2013. Manajemen Keuangan Teori.Konsep.dan Aplikasi. Penerbit : Ekonisia. Fakultas Ekonomi UII. Jakarta

Zulia Hanum. 2012. Pengaruh Profitabilitas Terhadap Modal Kerja pada Perusahaan Makanan dan Minuman yang Terdaftar di Bursa Efek Indonesia.Jurnal Manajemen \& Bisnis. ISSN: 16937619.vol 11 No.02 April 2012.
Ikatan Akuntansi Indonesia (IAI). 2015. Pernyataan Standar Akuntansi Keuangan (PSAK) No 1: Penyajian Laporan Keuangan. IAI. Jakarta 